ORIGINAL RESEARCH ARTICLE

\title{
A Literature Review of the Strategic Decision-Making Context: A Synthesis of Previous Mixed Findings and an Agenda for the Way Forward
}

\author{
Said Elbanna**', loannis C.Thanos², and Rob J. G. Jansen³ \\ 'Department of Management and Marketing, Qatar University, Doha, Qatar; 2Department of Business Administration, \\ Athens University of Economics and Business, Athens, Greece; '3epartment of Organization Studies, Tilburg \\ University, Tilburg, the Netherlands
}

\begin{abstract}
The aim of this article is to conduct a comprehensive literature review concerning the influence of contextual factors on strategic decision processes. Our literature review organizes the existing literature on contextual factors along the lines of an integrative framework for studying strategic decisions. Interestingly, the stream of research on strategic decision processes is dominated by studies showing mixed, contradictory, and inconclusive findings. The effects of each contextual factor on the strategic decision process differ substantially across the reviewed studies. This creates several opportunities for further research on the topic. The review also reveals a paucity of cross-cultural studies, longitudinal studies, and tests of complex relationships such as three-way interactions, curvilinear relationships, and mediation effects. We conclude our review by suggesting seven directions for future research and identifying several implications for theory and practice.
\end{abstract}

Keywords: Contextual Factors; Strategic Decision-Making Processes; Literature Review

Handling Editor: Thomas Roulet. Received: 21 November 2018; Accepted: 26 January 2020; Published: 2 June 2020

Following Mintzberg, Raisinghani, and Théorêt (1976, p. 246), a strategic decision can be defined as one which is "important, in terms of the actions taken, the resources committed, or the precedents set." Such decisions influence the success or failure of organizations (Dean \& Sharfman, 1996; Elbanna \& Child, 2007a; Walters \& Bhuian, 2004). These decisions are formulated and implemented in a context where managers have little power and control (Papadakis, Thanos, \& Barwise, 20l0). Hence, it is hard to trace their progress until we understand their broader context (Elbanna, Child, \& Dayan, 2013). This context is multifaceted, in the sense that the process of making strategic decisions is subject to several factors. Thus, it is very important to study in depth the role of the broader context because its characteristics do not necessarily impinge in isolation on the strategic decision process.

In the strategic management literature, there seems to be a consensus that context refers to sets of characteristics (Elbanna \& Child, 2007b; Papadakis et al., 2010) which include those of top management, decision-specific, environment and organization (e.g., Dayan, Elbanna, \& Di Benedetto, 2012; Papadakis, Lioukas, \& Chambers, 1998).

Previous reviews of the role of context in making strategic decisions create an informative overview of the contextual factors that impinge on strategic decision processes (Elbanna, 20 I0; Papadakis et al., 20 I0; Shepherd \& Rudd, 2014). The strength of these reviews lies in creating awareness of the integrative approach to context as an explanation for strategic decision processes and the ways in which they factor into the relationship between the process and outcomes of strategic decisions. Furthermore, they help managers to determine which contextual factors should be incorporated in their thinking for certain decisions and subsequent actions. However, these reviews do not contain in-depth discussions of the dimensions of strategic decision process. Even the reviews by Eisenhardt and Zbaracki (1992), Schwenk (1995), and Elbanna (2006), which focus on these dimensions, do not consider contextual influences.

*Corresponding author: Said Elbanna, Email:selbanna@qu.edu.qa 
To overcome the limitations of the above literature reviews, we carried out an in-depth review of the role of context in influencing strategic decision processes. The present review builds on and extends previous work by taking a closer look at the literature on the strategic decision process to identify more fine-grained research opportunities. By keeping the overview function of previous reviews, adding recent studies and exploring the extent to which context allows us to develop further insight into the reasons for mixed findings in this research area, we aimed to be more specific than previous reviews in drawing up a future research agenda. We hope that important areas for further research and appropriate approaches to studying strategic decision processes have been identified. For the present review, our research question is "How do contextual factors influence the strategic decision process?"

This allows for three contributions. First, by bringing together studies from several contextual perspectives, we map the broader context of strategic decision processes and enable an up-to-date integrative overview to be taken of the possible perspectives and the role of individual characteristics in the strategic decision process (Elbanna \& Child, 2007b). This integration opens the door to a better understanding of the reason why mixed findings persist. Second, the context perspectives may (due to their nature) be more logical as an antecedent (cause) of process and outcomes than as a boundary condition between process and outcomes (or vice versa). A further exploration of the main effects to see how they are reinforced, alleviated, attenuated, or exacerbated by specific characteristics or context perspectives also allows for a more fine-grained development of the framework. Therefore, by including several perspectives instead of only one researcher on the strategic decision process is more likely to identify reasons for the inconsistencies that are found. In addition, research on strategic decision processes does not provide a clear insight regarding the way in which context perspectives affect one another. For example, the external environment of a firm is connected to its internal environment through boundary spanners (Hautz, 2017; Jansen, Curşeu, Vermeulen, Geurts, \& Gibcus, 2013; Jemison, 1984). It is the relationship between context perspectives that is underexplored, in the sense that previous researchers focused on a single perspective, where multiple perspectives and their interrelationships were rarely examined. These then form two contributions that the present research makes. Together they allow us to draw up a third contribution, namely a future research agenda for context aspects in the strategic decision process research. As well as these contributions, practitioners will find more about the role of the various characteristics and perspectives, based on evidence from previous research. This will give them a better chance to disentangle which influences affect their strategic decision process and consequences, and how they do so.
In the next section, we describe the analytical approach and methodology that we used to conduct the literature review. After this, we present the results before identifying several theoretical and practical contributions of this study and outlining promising directions for future research.

\section{Organization and setup of the review}

The review is organized around the integrative framework presented in Figure I. This framework is a set of constituent parts linked together. The context factors on the left-hand side, the decision process in the middle, and the decision outcomes on the right-hand side make up the parts of the framework, and the links indicate the sequential, moderating, mediating, or cyclical nature of the relations between these parts.

Four groups of factors can be distinguished: they are the environmental context, organizational context, nature of the strategic decision, and top management characteristics. The environmental context refers to the external environment (environmental characteristics); the organizational context refers to the internal environment (organizational characteristics); the top management characteristics refer to the characteristics of the decision-makers on an individual or collective basis and the dynamics between them; and the decision-specific characteristics of strategic decision-making refer to the characteristics of the decision (Papadakis et al., 20l0). Previous empirical papers have explored and tested the effects of individual characteristics, and literature reviews have grouped and established the different parts of the broader context from which stems its influence on strategic decision processes and outcomes (Rajagopalan, Rasheed, \& Datta, 1993; Shepherd \& Rudd, 20|4).

The decision process refers to the process by which a strategic decision is formulated and implemented, that is, the process that leads to the choice of goals and means and the way that means are effectively deployed (Elbanna, 2006; Noorderhaven, 1995). Formulation concerns the way that the decision comes about, whereas implementation is about the way that the decision is put into action (Elbanna, 2006; Rajagopalan, Rasheed, Datta, \& Spreitzer, 1997). Decision outcomes are the intended (Papadakis et al., 1998; Shepherd \& Rudd, 2014) and unintended (Elbanna, 2018; Elbanna et al., 2013) consequences of the strategic decision process. Decision outcomes are the results of decision formulation and implementation and represent the direct organizational and social consequences of decision activity. Organizational performance is the actual outcome of the functioning of an organization. These definitions of context, process, and outcomes together form the backdrop against which we can place the individual papers of our review. 


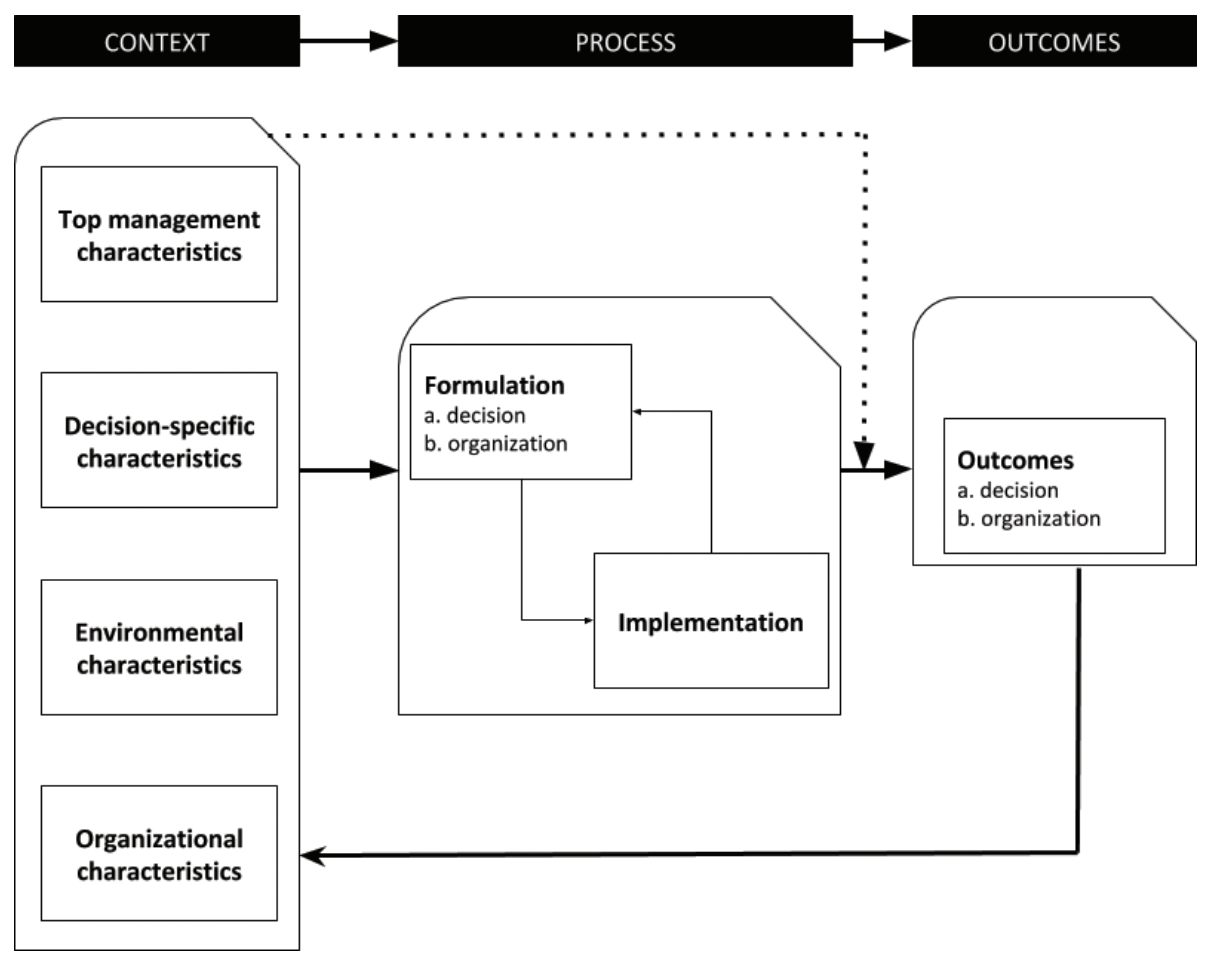

Figure I. The integrative framework for studying strategic decisions.

\section{Methodology: Sampling and coding}

We identified relevant articles by using various keywords in our search of the Social Sciences Citation Index (1988-20 I8), including strategic decision, strategic decision-making, strategic decision process, decision success, decision outcomes, and strategy process in the 'title' or 'topic' fields. We limited the search to the 'Business' and 'Management' categories in the Index, and we checked the list of references to previous literature reviews, that is, backwards snowballing of the literature (e.g., Eisenhardt \& Zbaracki, 1992; Elbanna, 2006; Papadakis et al., 20 I 0; Rajagopalan et al., 1993; Shepherd \& Rudd, 20 I4). The papers were retrieved through the EBSCO,ProQuest, Emerald, Science Direct, and JSTOR Business databases. Our systematic literature review resulted in 87 papers. These papers were included in the review if they had one or more concepts that fit one or more context perspectives, were about strategic decision processes, and were empirical in nature. Figure 2 reports the step-by-step search and selection process. Next, the included studies were coded in terms of their correspondence to the contextual factors included in the study.

\section{Contextual perspectives: Review of the literature}

The strategic decision process literature distinguishes four contextual perspectives, as shown in Figure I. These are the perspectives of top management (strategic or management choice), decision-specific characteristics, environmental determinism (environmental characteristics), and organizational characteristics. Factors incorporated in these perspectives directly influence the strategic decision process or moderate the relationship between the strategic decision process and its outcomes. The following sections create an overview of the four contextual perspectives and the empirical studies identified within each of these perspectives.

\section{Top management characteristics}

This perspective refers to the properties of the "top management team as the dominant coalition of the most senior executives who have responsibility for setting the overall direction of an organization" (Shepherd \& Rudd, 20 I4, p. 343). The external and the internal environments of the firm set limits to the decision process, but the final outcome of decisions is shaped by the top management team (Child, 1997). Several studies have adopted a strategic choice perspective and strategy-as-practice to investigate the effects of the top management team on strategic decision processes (e.g., Asmuß \& Oshima, 2018; Elbasha \& Wright, 2017; Ericson, 2010; Jansen, Curşeu, Vermeulen, Geurts, \& Gibcus, 20 I I). Other studies, though, have concluded that top management team characteristics may not impact strategic decision processes or that this impact is slight compared to other contextual characteristics (e.g., Lyles \& Mitroff, 1980). 


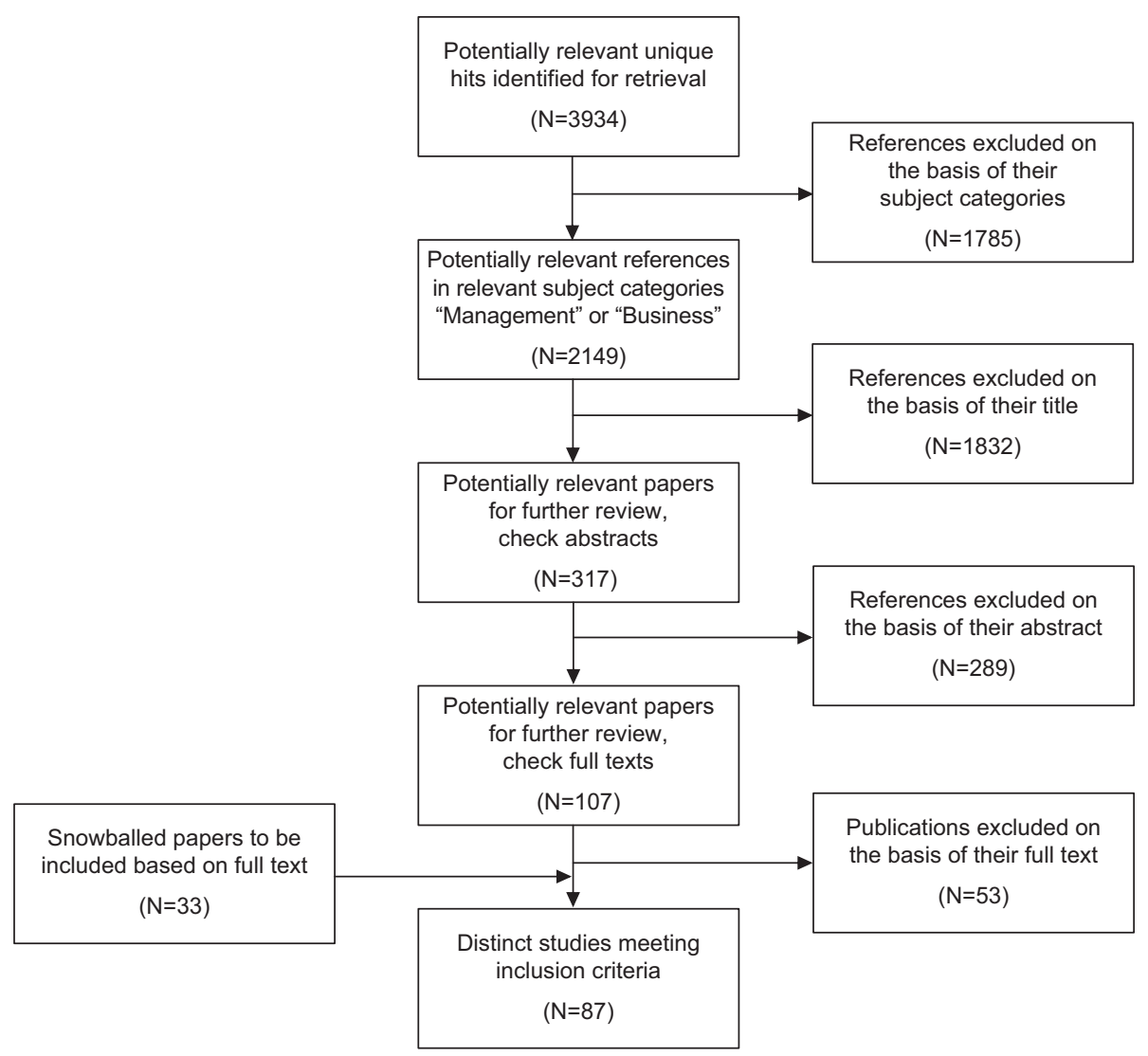

Figure 2. Flow diagram of the literature selection process.

Prior studies have considered either the demographic or the psychological characteristics of decision-makers. In the following paragraphs, we review the effects of both these characteristics on strategic decision processes.

\section{Demographic characteristics}

Several demographic characteristics such as gender, age, tenure, and education have been the subject of previous studies of top management teams (Elbanna, 20 I 8). Some studies have investigated the effects of such individual demographic characteristics on strategic decision processes. Others estimate the demographic diversity of top management teams, which refers to the extent to which a top management team is or is not demographically heterogeneous. The advantage of doing research with demographic data is that they are easily accessible to researchers (Finkelstein, Hambrick, \& Cannella, 2009). The wider the demographic diversity of the top management team, the greater the chance that this team will use multiple sources of information and perspectives in the decision process (Dutton \& Duncan, 1987). At this point, some scholars begin to argue that top management team diversity and performance are positively related (Wiersema \& Bantel, 1992). Yet, diversity has its costs since it makes communication more difficult and increases conflict and political behavior (Amason, 1996; Elbanna, 2009).

Generally speaking, recent reviews have concluded that several inconsistent findings have been made with respect to the relationship between demographic variables and strategic choices and strategic decision processes (Bromiley \& Rau, 2016; Hambrick, 2007). In the following paragraphs, we review the four most widely used demographic variables in the area of strategic decision processes, namely age, tenure, experience, and educational background.

Age. Age is an important factor affecting strategic decision processes (Finkelstein et al., 2009). On average, older managers appear to be more risk averse than younger ones and incline to more incremental decisions about their organizations (Brouthers, Andriessen, \& Nicolaes, 1998; Wiersema \& Bantel, 1992). Similarly, Greening and Johnson (1996) argue that younger managers appear to adopt more analytical or rational approaches when making and integrating strategic decisions. Other studies have argued that managers' age is not as 
important as tenure in the firm (Bantel, 1993). Surprisingly, Francioni, Musso, and Coppi (2015) find mixed results: age is not related to the rationality dimension of the strategic decision process, but is negatively related to the political behavior of this process.

Similarly, research on the role of age heterogeneity in decision-making showed mixed results, such as a variety of perspectives on decision-making (Wiersema \& Bantel, 1992), enhancing the capacity of firms to develop responsive practices in the face of threats (Greening \& Johnson, 1996) and having no effect on strategic change (Wiersema \& Bantel, 1992).

Tenure. Tenure potentially has the most significant theoretical bearing of all the demographic characteristics on decisions (Finkelstein et al., 2009). It has been linked to organizational performance, innovation, and risk-taking by top management teams (Henderson, Miller, \& Hambrick, 2006; Wu, Levitas, \& Priem, 2005). Previous upper-echelon studies have measured several different types of tenure (see Finkelstein et al., 2009 for an overview). The most widely studied ones are tenure in the top management team, captured by the number of years the members of the team have worked together; tenure in position, measured by the number of years the executives have been in their position; organizational tenure, measured by the number of years that the executives have worked in the firm and their tenure in the industry representing the time spent in the industry. But our search of the literature found no studies in the strategic decision process area that investigated the effects of industry tenure on strategic decision processes.

Empirical studies have argued that tenure, like age, increases rigidity (Greening \& Johnson, 1996). The studies by Fredrickson and laquinto (1989) and Goll and Rasheed (2005) conclude that long-tenured top management teams follow more rational approaches to decision-making. Other studies have reached the conclusion that the wider the variation of tenure in the top management team, the more effective the teams are (Greening \& Johnson, 1996; Schwenk, 1988; Wiersema \& Bantel, 1992).

Experience. In the strategic decision process research, two aspects of experience are important: amount and type. The overwhelming majority of studies focus on the former and not the latter. Fredrickson (1985) reports that contextual factors influence the strategic decision processes of inexperienced executives, although they may not affect the strategic decision processes of experienced executives. Similarly, Elbanna and Child (2007b) argue that, contrary to US and British managers, Egyptian managers' limited experience may lead them to focus on managing strategic decisions within their organizational context more than on the environmental variables in which they make them. However, Elbanna and Fadol (2016a) contend that the impact of the contextual variables on the strategic decision process varies from one dimension to another.
The amount of experience in Dutch small and medium-sized enterprises (SMEs) leads to more effective decisions if decision-makers are more confident about the decision situation (Jansen et al., 20 I 3), but show no effect if decision-makers are willing to accept more risk in the decision situation. This mixed effect of experience according to the amount of experience is not exceptional, for recent studies have also shown that relations between experience measures and the characteristics of the strategic decision process are expected, but are not found. Experience in the top management team (measured as the number of industries in a manager's experience) does not lead to greater potency in the top management team (Clark \& Maggitti, 20I2). Francioni et al. (20I5) found no effects of the CEO's experience on the strategic decision process in Italian SMEs, measured by the number of years, for either the political behavior dimension or that of rationality. This shows that the role of the amount of experience is two-edged with regard to explaining the characteristics of the strategic decision process and outcomes. Some limited evidence exists to support the view that the type of experience influences strategic decision processes, as well (Hitt \& Ireland, 1986).

Some studies have also focused on the effects of heterogeneity in functional experiences on strategic choices and strategic decision processes. The available empirical evidence holds that heterogeneous teams make better decisions than homogeneous teams do (Greening \& Johnson, 1996; Schwenk, 1988). In summary, both the amount of experience and the type of experience are clearly related to the strategic decision process and outcomes, but in the studies we reviewed they have no similar effect.

Educational background. The educational background of executives determines how they perceive the world, process information, and ultimately make decisions (Hambrick \& Mason, 1984). Goll and Rasheed (2005) contend that, because business management education focuses on applying analytical techniques to decision-making, educated managers are initially led to rely on rational strategic decision processes rather than other approaches. Clark and Maggitti (2012) found that the education level in the top management team is positively related to the speed of strategic decision-making through the potency of the team. Francioni et al. (20I5) found that higher education levels lead to more rationality in the strategic decision process. Taken together, the education level seems to play a salient role in the strategic decision process, and its impact on decision outcomes goes through process characteristics.

Moreover, the type of education (a.k.a. specialization) is an important determinant of strategic decision processes. A manager's specialism in education forms his/her perspective and outlook (Wiersema \& Bantel, 1992). Alkaraan and Northcott 
(2006), for example, argue that the specialization of education of CFOs in the UK is reflected in the strategy that their companies follow.

\section{Psychological characteristics}

In addition to the demographic characteristics, previous studies have investigated the effects of several psychological characteristics on strategic decision processes, such as locus of control, need for achievement, and risk-taking propensity, which we discuss next.

Locus of control. Rotter, on the basis of social learning theory, developed the locus of control construct, which refers to "individual differences in a generalized belief in internal versus external control of reinforcements" (Rotter, 1966 in Boone, De Brabander, \& van Witteloostuijn, 1996, p. 668). While internal individuals feel that they can control their lives, the opposite holds for external individuals (Selart, 2005). Locus of control has been linked in previous studies with several outcomes, including organizational performance, innovative behavior, and export behaviors (e.g., Halikias \& Panayotopoulou, 2003). In a pioneering study, Miller, Kets De Vries, and Toulouse (1982) found that firms with internal CEOs emphasize product design innovations through R\&D and change their products more frequently than firms with external CEOs. Miller and Toulouse (1986) further argued that internal CEOs favor decentralized strategic decision processes. However, in a study of 204 Hong Kong Chinese managers, Cheng, Rhodes, and Lok (2010) argue that there is no statistically significant relationship between locus of control and rationality in the strategic decision process.

Need for achievement. The need for achievement is a second important personality characteristic. It reflects the tendency of a manager to accomplish tasks and achieve success. "Achievers would rather set their own goals, which are of moderate difficulty, than have goals set for them by others" (Hitt, Miller, \& Colella, 2009). Moreover, they are ambitious, competitive, and keen to exercise control over the events affecting their lives (Miller, Dröge, \& Toulouse, 1988). Based on this desire to control the context in which they operate, "Achievers" favor structural centralization and emphasize formalized strategic decision processes (Lewin \& Stephens, 1994). Miller et al. (1988) argued that executives' high need for achievement causes them to aim for their goals in an orderly and systematic way, thus taking a more rational approach, but other writers found no empirical support in a recent study based on Italian SMEs (Francioni et al., 2015); instead, a positive effect of the need for achievement on political behavior was found.
Risk-taking propensity. Some studies have investigated the effect of top managers' risk-taking propensity on strategic decision processes. Wally and Baum (1994), for example, suggest that risk-taking propensity positively influences the pace of evaluating candidates for acquisition. Gilley, Walters, and Olson (2002) concluded that risk taking by the top management team and firm performance are positively related in stable rather than in dynamic settings. Francioni et al. (20।5) found that managers' risk attitude positively affects their rationality and political behavior.

\section{Other studies}

Quite a few studies have investigated other characteristics besides those mentioned above. For example, Talaulicar, Grundei, and Von Werder (2005) argued that debate by the top management team influences the comprehensiveness of decisions in a positive way. Ashmos and McDaniel (1996) reported that managers should pay attention to questions of both scope and intensity of participation in the decision process. Souitaris and Maestro (2010) found that polychronicity in top management teams, a construct referring to the tendency of top managers to do several tasks simultaneously, positively influences firm performance. This influence is mediated through comprehensiveness and speed. In another study in the Chinese context, it has been argued that speed is positively influenced by a CEO's transformational leadership (Gu, Weng, \& Xie, 2012). A CEO's transformational leadership has also been found to exert a positive influence on the comprehensiveness of strategic decision processes (Friedman, Carmeli, \& Tishler, 2016), whereas relation leadership positively affects team learning in strategic decision processes (Carmeli, Tishler, \& Edmondson, 20। 2).

Papadakis and Barwise (2002) argued that the characteristics of the CEO (e.g., tenure in position, education, risk-taking propensity) and those of the top management team (i.e., education, competitive aggressiveness) are important determinants of strategic decision processes, with the latter being more important. Another interesting finding was that the broader context (i.e., hostility, firm size, ownership type, decision importance) is more influential in this regard than the CEO or the top management team. Papadakis (2006) concluded that a CEO's demographic characteristics influence strategic decision processes while his/her personality characteristics exert no direct influence. The latter inference is consistent with the findings of Cheng et al. (2010) in the Chinese context, but contradicts the early findings of studies from the US context (e.g., Miller et al., 1988).

The effects of several other psychological constructs on strategic decision processes have been identified in the literature. For example, some limited empirical evidence exists to 
support the view that CEO meta-cognition (Mitchell, Shepherd, \& Sharfman, 2011), executives' cognitive style (Nutt, 1990, 1993), cognitive complexity (lederan, Curşeu, \& Vermeulen, 2009), shared mental models (Bailey \& Peck, 20l3), and job anxiety (Mannor, Wowalk, Bartkus, \& Gomez-Mejia, 20l6) influence strategic decision processes. Clearly, more research is needed before drawing any conclusions.

\section{The decision-specific characteristics perspective}

Hutzschenreuter and Kleindienst (2006) point out that the role of decision-specific factors in the strategic decision process has received limited attention from scholars, and hence, it is hard to generalize the results of previous research because of two factors. In this review, we will discuss decision importance, uncertainty, and motive, since these are the most widely studied characteristics in the strategic decision process literature (Fredrickson, 1985; Hickson et al. 1986; Nooraie, 2008).

\section{Decision importance}

Some strategic decisions are more important than others (Dean \& Sharfman, 1996; Elbanna, 2010; Shepherd \& Rudd, 20।4), and hence, decision-makers may make strategic decisions in different ways because of the limits on their time and attention. For instance, conventional wisdom would suggest that for strategic decisions that are likely to be very important for the future of the firm, companies will collect great amounts of information and will employ structured and quantitative techniques in analyzing this information. In other words, the higher the decision importance, the higher the level of rationality in the strategic decision processes. A few studies have supported this argument (e.g., Judge \& Miller, 1991; Nooraie, 2008). However, Dean and Sharfman (1993a) found that rationality and decision importance are not related to each other. Similarly, Elbanna and Fadol (2016a) report the absence of a significant relationship between decision importance and intuition. The inconclusiveness of this evidence suggests that additional research is necessary to more precisely understand the role of decision importance in the strategic decision process.

\section{Decision uncertainty}

Decision-making is characterized by uncertainty (Noorderhaven, 1995). Decision uncertainty exists when decision-makers face complex and novel problems along with unclear relationships between their means and ends (Sharfman \& Dean, 1997).

While decision uncertainty increases the use of political behavior (Lyles, 1981; Papadakis et al., 1998) and intuition (Elbanna \& Fadol, 2016a) in strategic decision processes, there are two views about its impact on rationality. First, if the decision entails high levels of uncertainty, then managers will employ rational strategic decision processes. The logic behind this is that the only way to reduce uncertainty is by collecting and analyzing great amounts of information from the external and internal environment (Bourgeois \& Eisenhardt, 1988). A version of this argument, combined with the politicization reported by Papadakis et al. (1998) and Lyles (1981), can be found in the study by Denis, Dompierre, Langley, and Rouleau (20| I).

The second view regarding the relationship between decision uncertainty and rationality suggests that the former reduces the latter (e.g., Dean \& Sharfman, 1993a). Uncertainty curtails rationality in strategic decision processes (e.g., Butler, 2002). Two further studies show that decision uncertainty increases the use of intuition (Elbanna, Child, \& Dayan, 2013; Hensman \& Sadler-Smith, 20 I I).

\section{Decision motive}

Several authors consider whether the strategic decision motive is made in response to an opportunity or to a threat/crisis (Shepherd \& Rudd, 2014). Managers react differently if a decision is motivated by an opportunity or a crisis (Hurt \& Abebe, 2015; Jackson \& Dutton, 1988). Decision motive influences several aspects of strategic decision processes, such as who will be involved, how, when, and the amount of resources that are needed (Ashmos, Duchon, \& McDaniel, 1998; Dutton, Stumpf, \& Wagner, 1990; Fiegener, 2005). Fredrickson (1985) found that comprehensiveness in strategic decision processes increases if a decision is driven by a crisis. Although decision motive influences several aspects of strategic decision processes such as who will be involved, how, when, and the amount of resources involved (Ashmos et al., 1998; Dutton et al., 1990; Fiegener, 2005), the results in the literature are not consistent and it is hard to generalize (Elbanna \& Child, 2007a).

\section{The environmental determinism perspective}

According to this perspective, the external environment and its characteristics drive strategic decision processes (Elbanna \& Gherib, 2012; Hitt \& Tyler, 1991; Le Bris, Madrid-Guijarro, \& Martin, 2019). We can divide earlier studies on the role of the environment in the strategic decision process into two categories. The first category contains studies which examine environmental attributes as determinants of the strategic decision process dimensions (Elbanna, 20I5; Meissner \& Wulf, 20l4). The second category contains studies which investigate the moderating role of environmental attributes on the effects of strategic decision processes on outcomes (e.g., Mueller, Mone, \& Barker, 2007; Walters \& Bhuian, 2004). Before discussing the 
role of two important environmental characteristics, environmental uncertainty and hostility, in making strategic decisions, we briefly address how external control may affect the strategic decision process.

\section{External control}

External control refers to the influence of external factors, such as government agencies, trade unions, creditors, clients, or suppliers, on organizational activities, including strategic decisions (Child, Elbanna, \& Rodrigues, 20l0). The assumption with this perspective is that any organization, as part of a larger world, is an open social system which interacts with other parties (Hickson et al., 1986). When decisions are reviewed by outsiders, decision-makers try to persuade those who have control over them that their strategic decision process is rational and their choices are therefore valid (Langley, 1989). Dean and Sharfman (1993a), however, found that external control reduces rationality. $A$ possible explanation of this interesting result is that external control may not provide organizations with the managerial discretion necessary to adopt rationality in strategic decision processes and thus to adapt to or follow institutional logics (Greenwood, Magan Diaz, Li, \& Cespedes Lorente, 2010).

\section{Environmental uncertainty}

Environmental uncertainty is the combination of two dimensions: dynamism and complexity. Several scholars have highlighted the difficulties of making decisions in dynamic or highly complex situations (Le Bris et al., 2019; Fredrickson \& laquinto, 1989); hence, environmental uncertainty has received substantial empirical attention from scholars (Elbanna, Kapoutsis, \& Mellahi, 2017). Prior scholars, drawing on contingency theory, have argued that uncertainty has a moderating impact on the effects of strategic decision processes on firm performance. However, several inconsistent results have been published. For example, one stream of research has concluded that rationality leads to better outcomes in stable environments (Fredrickson, 1984; Fredrickson \& Mitchell, 1984; Hough \& White, 2003). Another stream of research has argued in favor of exactly the reverse (e.g., Glick, Miller, \& Huber, 1993; Priem, Rasheed, \& Kotulic, 1995; Walters \& Bhuian, 2004). Finally, several studies (Dayan et al., 2012; Dean \& Sharfman, 1996; Elbanna, Ali, \& Dayan, 20 I I; Elbanna \& Child, 2007a; Elbanna et al., 20I3) have found that uncertainty is not a significant moderator in the relationship between strategic decision processes and performance.

Mitchell et al. (201 I) found that while in dynamic environments uncertainty is high and one would expect to find it hard to be consistent in one's judgment, the subjects in their study were more consistent in taking strategic decisions. Elbanna, Di
Benedetto, and Gherib (2015a) found that when one faces high unpredictability concerning changes in product demand, the negative effect of political behavior on decision success intensifies. In addition, different types of environmental uncertainty, such as technology uncertainty and sophistication, and demand uncertainty can be distinguished (Atuahene-Gima \& Li, 2004; Covin, Slevin, \& Heeley, 200 I).

To sum up, previous studies have argued that uncertainty can moderate positively, negatively, or not at all the effects of rationality on performance. Several possible methodological reasons (e.g., different ways to operationalize uncertainty and different settings) and substantive reasons (e.g., different conceptualization and other variables incorporated in the research models) may contribute to the explanation of these contradictory results (for more discussion on this issue, see Boyd, Bergh, Ireland, \& Ketchen, 2013; Dayan et al., 2012; Elbanna, 20 I0). The study by Klingebiel and De Meyer (2013) may shed some light on the interplay of environmental uncertainty and the strategic decision process. These writers propose that differences in awareness and uncertainty can explain the observed variation in the strategic decision processes during implementation, that is, the adaptation becomes subject to selectiveness, deliberateness, and diligence. Their study implies that the certainty of a future event and the awareness of this event by the decision-maker play a major role in whether the strategic decision process becomes increasingly rational or less so.

\section{Environmental hostility-munificence}

Environmental munificence is an important environmental attribute that refers to the ability of the environment to support the business of firms (Dess \& Beard, 1984). There is increasing interest in the relationship between environmental munificence/hostility and strategic decision processes. Mitchell et al. (201 I) found that in hostile environments, decision-makers with wide metacognitive experience are less consistent in their decision-making. Several studies show that environmental munificence/hostility acts to limit the effects of strategic decision processes on organizational outcomes (Elbanna \& Child, 2007a; Elbanna et al., 20 I3; Goll \& Rasheed, 1997). Other studies found a significant effect of environmental hostility and both analysis (Miller \& Friesen, 1983) and conflict (Elbanna, 2009). Given that Papadakis et al. (1998) reported that hostility and strategic decision processes are not directly related, it becomes clear that the evidence on the role of environmental hostility/munificence is not generalizable. As discussed in the environmental uncertainty section, the conflicting results are most probably due to many methodological features and substantive differences (see Boyd et al., 2013). In conclusion, environmental characteristics display mixed results. 


\section{The organizational characteristics perspective}

A variety of organizational factors influences the strategic decision process, which in turn leads to organizational outcomes. Alternatively, some authors investigate the moderating effects of such factors on the linkage between strategic decision processes and decision outcomes. This study reviews three organizational variables that have been widely considered in prior studies. These are organizational performance, company size, and type of ownership.

\section{Organizational performance}

The literature on strategic decision processes reports inconsistent findings on the nature of the relationship between past firm performance and rationality in strategic decision processes. For example,Amason and Mooney (2008) concluded that poor past performance will increase the comprehensiveness of strategic decision processes. The opposite finding has been reported by other researchers (e.g., Papadakis et al., 1998). Elbanna et al. (2013) found that past performance and intuition are not related. Elbanna, Thanos, and Colak (20I5c) and Francioni et al. (20I5) found a positive relationship between past performance and the quality of decision implementation and rationality. Ashmos et al. (1998) reported the influence of past performance on participation in the strategic decision process. Of interest is that different aspects of performance may influence differently the strategic decision process dimensions (for more information, see Elbanna \& Naguib, 2009; Elbanna,Thanos, \& Papadakis, 20 I4).

Another strand of this research examines the impact of strategic decision processes on different organizational outcomes such as decision effectiveness (e.g., Jansen et al., $201 \mathrm{l}$; ji \& Dimitratos, 2013; Nooraie, 2008), speed (e.g., Amason \& Mooney, 2008), commitment (e.g., Parayitam \& Dooley, 2009), creativity (e.g., Dayan \& Di Benedetto, 201 I; Ford, Sharfman, \& Dean, 2008), and firm performance (e.g., Baum \& Wally, 2003; Dimitratos, Thanos, Petrou, \& Papadakis, 201 l b; Miller, 2008; Mueller et al., 2007; Simons, Pelled, \& Smith, 1999).

Unfortunately, none of the studies above opted for a longitudinal/panel-type approach, such that performance as outcome could also function as an antecedent of the strategic decision process. Although the studies reviewed so far examine the relationship between strategic decision processes and performance, performance may moderate the effects of strategic decision processes on outcomes. Only one study has examined this critical issue, namely Elbanna and Child (2007a). Clearly, we need more of such studies. Adjacent areas that focus on aspiration levels and performance feedback thinking may provide inspiration looking at the role of previous organizational performance, since these studies build explicitly on the behavioral theory of the firm and focus on adaptive decision behavior (Gavetti, Greve, Levinthal, \& Ocasio, 20l2).

\section{Company size}

Although its importance has long been recognized, the findings regarding the relationship between company size and strategic decision processes are mixed. A line of research argues that the size of an organization has a profound impact on its strategic decision processes. For instance, Fiegener (2005) found that the company's size encourages the board to take part in its strategic decision process. Elbanna et al. (2013) reported that large firms follow less intuitive decision processes. Brouthers et al. (1998) argued that managers in small firms use intuitive rather than rational strategic decision processes, while, according to Fredrickson and laquinto (1989) and Elbanna (2010), in large firms, executives rely on rational/comprehensive approaches. It was also found that size negatively affects agreement in the top management team (laquinto \& Fredrickson, 1997). On a related note, Duhaime and Baird (1987) argued that managers of larger firms exhibit lower levels of involvement than managers of small firms. Interestingly, though, Dean and Sharfman (1993a) have not found any relationship between firm size and strategic decision processes.

Similar inconsistent findings have also been reported as far as the moderating impact of size is concerned on the effects of strategic decision processes on decision performance. All these inconsistent findings could be attributed to differences in the research methods and measures adopted in studies and call for more research on the topic.

\section{Type of ownership (corporate control)}

Some studies investigate the relationship between strategic decision processes and the type of ownership or corporate control. Papadakis et al. (1998), for example, reported a significant influence of the type of control on several aspects of the strategic decision process. Elbanna (2012) contended that more researchers should investigate the critical role of type of ownership in shaping strategic decision processes in both public and private organizations. The available evidence seems to suggest major differences between the dimensions of decision processes in public and private organizations, but more empirical evidence is unquestionably needed to reach robust and generalizable conclusions.

\section{Other studies}

Two additional topics emerged in our analysis of the strategic decision process literature. These are strategic performance measurement (systems) and strategic control. The latter, strategic control refers to the alignment of managers' performance with the organization's key objectives. In this regard, Elbanna (2016) found that if strategic control was higher, less political behavior was encountered or displayed. The former, 
strategic performance measurement (systems) refers to sets of metrics that track the performance of an organization in different areas, that is, they "present distinctive features such as: (I) the integration of long-term strategy and operational goals; (2) the provision of performance measures in the area of multiple perspectives; (3) the provision of a sequence of goals/metrics/targets/action plans for each perspective; and (4) the presence of explicit causal relationships between goals and/or between performance measures" (Bisbe \& Malagueño, 2012, p. 297). Bisbe and Malagueño showed that organizational performance benefits from the use of this system. Abdel-Maksoud, Elbanna, Mahama, and Pollanen (2015) and Pollanen, Abdel-Maksoud, Elbanna, and Mahama (2017) found that the use of performance information increases and benefits organizational performance, but different types of metrics and decisions are effective in different ways. Metrics of efficiency contribute through their use of information to both decisions on strategy implementation and evaluations of strategy, but metrics of effectiveness do not. These measurement systems can encapsulate past performance and they can also cover substantially more aspects of an organization's performance.

\section{Patterns across contextual characteristics}

In this section, we report on two patterns that surfaced in our analysis. These patterns highlight some of the longstanding discussions in the research on the strategic decision process that have not been tackled satisfactorily and are as yet contradictory.

The first pattern focuses on what process means and as such describes some of the epistemological assumptions hitherto adopted by strategic decision process studies. From the reviewed papers, it became clear that certain meanings of process are represented more than others. Van de Ven (1992) described three meanings of the word process that offer guidance for research designs on strategic decision processes (Szulanski, Porac, \& Doz, 2005): "(I) a logic that explains a causal relationship between independent and dependent variables, (II) a category of concepts or variables that refers to actions of individuals or organizations, and (III) a sequence of events that describes how things change over time."

Whittington (2016) described process meaning (I) as extracting strategy processes from organizations and treating them as essentially inanimate things in which the complexities of the process become tractable by rubbing out the sequences that link the event and subsequent outcome; a process story or logic is used in such studies to explain why an independent (input) variable exerts a causal influence on a dependent (outcome) variable (Van de Ven, 1992).

Process meaning (II) focuses on strategy processes as discrete processes, infuses them with life and dynamism, and emphasizes their dynamics (Whittington, 2016). Usually, these studies capture process in concepts that are operationalized as constructs and measured as fixed entities (variables) (Pettigrew, 1992; Van de Ven, 1992). While these studies capture the temporal aspects of strategic decision processes better than those under process meaning (I) by tracing the sequence of events across (long) periods of time (Pettigrew, 1992), their capacity to do so is limited by focusing on attributes of strategic decision processes which can vary along numerical scales from low to high. Process meaning (III) explicitly and directly observes processes in action and thereby can describe and account for the way in which some entity or issue develops and changes over time. It is this third view of process meaning that takes a historical developmental perspective and thereby focuses on "the sequences of incidents, activities, and actions unfolding over time" (Pettigrew, 1992, p. 7). The focus lies on the sequences of incidents, activities, and stages that unfold over the duration of a central subject's existence (Van de Ven, 1992). It is this third meaning of process that is usually considered as capturing process in the fullest way, because it captures "reality in flight" and outcomes are attributed a meaning, which is not the same as the first two meanings convey (Langley, 2007; Van de Ven, 1992). Rather than having the status of 'final outcomes,' these first two meanings can be considered inputs to ongoing processes, since their evaluations and interpretations can have important effects on subsequent actions (Langley, 2007; Langley \& Abdallah, 20 I I).

Distinguishing between process meanings allows scholars to better understand the conceptual basis of the reviewed research and when taken together these meanings help us to identify promising directions in the strategic decision process research. Process studies generally address questions about how and why things emerge, develop, grow, or terminate over time (Langley, Smallman, Tsoukas, \& Van de Ven, 20 I3). Hence, it was surprising to find relatively few studies that used an elaborate form of processual analysis (process meaning III) to explain the links between context, process and outcomes (Langley, 2007; Pettigrew, 1997; Whittington, 2016). The number of papers across the three process meanings is rather skewed, with process meaning (I) represented in 26 studies (29.9\%), process meaning (II) represented in 52 studies (59.8\%), and process meaning (III) represented in 9 studies (10.3\%). Although the type of research demands much in the way of resources and time, it would provide a more close and accurate understanding of the temporal evolution of things or substances in strategic decision processes if more studies viewed strategic decision processes from the perspective of process meaning (III) (Langley \& Tsoukas, 20 I6).

The implication of this first pattern is that the knowledge derived from studies on strategic decision processes may inform practitioners about relevant input, throughput, and 
output aspects of the strategic decision process in a discrete sense (process meanings I and II). However, it is less capable of teaching them how to act or guiding them in improving their performance (Langley, 2007), and they will learn little from it about the links between the actions that lead to the formulation and support of strategic processes and decisions in their context and in relation to the intended and unintended outcomes, that is, how things move along in the strategic decision process (Huff \& Reger, 1987; Pettigrew, 1997; Whittington, 2016). It is ultimately the ordering of the process and the agents involved in it (the organization and the strategy-makers), the issue to be decided on, and the sequence of actions that leads to decisions and drives them along (Hutzschenreuter \& Kleindienst, 2006). The spatial and temporal ordering and arrangement of these elements during the strategic decision process gets us close to the way that strategic decisions actually happen. Such an approach may help to overcome the limitations traditionally associated with research that resembles process meanings (I) and (II), that is, reification when research moves too far from the actual strategic decision process; dehumanization when agency and what agents do in the strategic decision process are downplayed; and isolation of the strategic decision process as a discrete process from the wider strategy or organizational processes (Langley, Mintzberg, Pitcher, Posada, \& Saint-Macary, 1995). Still, this should not be seen as a plea to focus only on the particularly elaborate process meaning (III) when researching the effect of context on strategic decision processes. Rather, the deep insights derived from this process meaning can be productively used to complement the more widely available knowledge derived from studies of process meanings (I) and (II).

The second pattern focuses on the research design, data collection methods, measurement strategies, and sampling procedures used by studies for analyzing the process meanings presented above. With respect to the research design, the first bias refers to the adoption of cross-sectional research designs by most of the studies grouped in all process meanings and the shortage of longitudinal studies. While there is generally nothing wrong with using cross-sectional data in principle, their use should be avoided in studies that aim to identify causality or change, which is the case for process meanings (I) and (II). In other words, the coherence between the research question and research design can be further improved in research on strategic decision processes. With respect to data collection methods we noticed a second bias. The overwhelming majority of reviewed studies follow a deductive approach emphasizing a quantitative research design. We were able to list only a few qualitative papers (e.g., Calabretta, Gemser, \& Wijnberg, 2017; Eisenhardt, 1989; Langley, 1989; Mintzberg et al., 1976). We view this lack of balance as a little problematic because qualitative studies allow for an in-depth understanding of the way in which context shapes process over time, yielding useful implications for managers and policy-makers (Eisenhardt, 1989; Langley et al., 1995).

As a third bias, with respect to measurement strategies, we noticed in the quantitative studies that the strategic decision process is full of inconsistencies in terms of labeling, defining, and measuring key constructs. This is not new in the strategic decision process area and has been highlighted by prior literature reviews as a substantive priority for future studies to remedy (Elbanna, 2006; Forbes, 2007; Papadakis et al., 2010). The most popular example is that of rationality, which has been labeled as procedural rationality, analysis, and comprehensiveness and has been measured with the use of several different scales. This situation is also found in other dimensions of the strategic decision process such as politics (often labeled "politicization" or "political behavior" and measured with different scales) and intuition or intuitive synthesis. The use of different labels and measures of the same construct may lead to different empirical findings and reduce the chance of conducting meta-analyses. We view the latter as a notable limitation of the field, given that meta-analyses allow cumulative knowledge to be amassed (Samba, Tabesh, Thanos, \& Papadakis, in press). With respect to sample selection, we noticed as a fourth bias that research on strategic decision processes has mainly taken place in the United States, mostly emphasizing manufacturing firms. Several studies have argued that the results of these studies may not be generalizable to other national or industry settings (e.g., service industries) and have called for more research to investigate the effects of national culture on strategic decision processes (e.g., Cardinal, Miller, Kreutzer, \& Tenbrink, 20I5; Elbanna, 2006).

Evidently, much more research is needed before we have an adequate understanding of the impact of national culture on the strategic decision process. The best way to do this is through research in other countries than the USA and cross-cultural studies in several national settings. We were able to identify several recent papers relying on non-US data. For example, we were delighted to see that in recent years, researchers have used samples of British (e.g., Thomas \& Ambrosini, 2015), Irish (e.g., Heavey, Simsek, Roche, \& Kelly, 2009), Italian (e.g., Francioni et al., 20 I5), Greek (e.g., Thanos, Dimitratos, \& Sapouna, 2017), German (e.g., Meissner \& Wulf, 20l4), Dutch (e.g., Jansen et al., 2013), Egyptian (e.g., Elbanna \& Child, 2007a), United Arab Emirates (e.g., Elbanna \& Fadol, 20 l 6b), Turkish (e.g., Elbanna et al., 2015c), and Malaysian (e.g., Nooraie, 2008) firms. Only a few scholars have relied on cross-national samples (see, e.g., the study by Dimitratos, Petrou, Plakoyiannaki, \& Johnson, 20 I la). Still, most strategic decision process studies continue to focus on manufacturing at the expense of service firms. 


\section{Theoretical and practical implications}

Based on the preceding review of empirical research on strategic decision processes, several implications for theory and practice can be identified. These types of implication will be discussed in turn.

\section{Theoretical implications}

First, our review leads us to conclude that some patterns across contextual perspectives can be observed. Notably, two patterns have been identified which help to explain why mixed or conflicting findings persist. The first pattern, describing the extent to which different meanings are attached to process in the sense of "strategic decision process," shows that there is a skewed distribution between the three types distinguished by Van de Ven (1992), with a de-emphasis on the process meaning that approximates most closely to a pure process approach to studying strategic decision processes. In addition, these variations between process meanings appearing within an individual contextual perspective propagate mixed findings, due to the inconsistent focus of studies on different process meanings, while claiming that they add to the same aspects and meaning of process. The second pattern describes the extent of bias in several aspects of the research set-up and methodology. This bias illustrates the variety of approaches and methodologies to study the same phenomenon or relationship, here the strategic decision process and its relationship with contextual perspectives. Since this appears from an individual contextual perspective, it propagates mixed findings due to the inconsistent focus of studies on the constructs and other aspects of the research set-up and methodology, as is observed in several areas of strategic management (Boyd et al., 2013; Ketchen, Boyd, \& Bergh, 2008). This in turn leads to more scattered than connected insights. In combination, these patterns give us strong indications why mixed findings persist in the research on strategic decision processes.

Second, when the strategic decision process research includes multiple contextual perspectives, these often play different roles. For example, organizational characteristics, if not used as antecedents of the strategic decision process, are often used as control variables next to top management characteristics, which are used as antecedents. Similarly, environmental characteristics are often used as moderating variables in the process-outcomes relationship. Our analysis of the literature thus shows that influences derived from multiple contextual perspectives are used jointly in this research field. However, given the inconsistency in addressing the role of different contexts, in terms of the types and number of perspectives considered, we can only contribute some ways of regulating research. It is impossible at this stage to provide a fully integrated picture of why strategic decision process studies are inconsistent with each other.
Third, as discussed below, this review led us to identify four compelling directions for future research and three further avenues of interest. It highlights the inference that part of the research agenda on this topic, as stated in previous reviews and empirical articles, is still unfulfilled. Some progress has been made in the four compelling areas, but not so much as to claim that we have solved the largest part of the puzzle they present. The further avenues of interest indicate that it is time for research on strategic decision processes both to "borrow concepts" from adjacent strategic management fields and to let others "borrow concepts" more recognizably from the existing research on strategic decision processes. In this regard, the research on entrepreneurial decision-making, while encouraging in its present growth, hardly connects directly to research on strategic decision processes. With respect to borrowing concepts from adjacent fields of strategic management, comparing direct measurements with archival measurements requires bridges with, for example, interactional approaches to strategy and behavioral and micro-foundations approaches, which focus on applying cognitive and social psychology. In other words, next to the field-specific agenda, our review also shows that researchers should interact across the boundaries of the field.

\section{Practical implications}

Two specific practical implications follow from this review, namely (I) the presence of multiple influences and (2) the need to consider the links between contextual perspectives and their different roles. Both implications are discussed below.

First, practitioners are well aware of the complexity and uncertainty that surround strategic decisions and strategic decision processes. Hence, they are aware of the presence of multiple influences that need their attention. This set may not be the same set of influences for every strategic decision process. Moreover, given the scarcity of integrative studies of the effect of context on the strategic decision process, practitioners should be wary of relying on studies that present a narrow view of the context of strategic decision processes. The present review did not designate any 'most important' or 'most salient' influence. Studies that incorporate influences on the strategic decision process from a single or limited set of contextual perspectives and only a single dimension of the strategic decision process can thus be considered too narrow to rely on, unless the empirical setting is very similar to the one that the practitioner has. Since this is rarely the case, however, we would ask practitioners to weigh such studies carefully and rely on more broad and integrative studies of influences on the strategic decision process. We would also recommend them to consider studies where at least three out of four possible contextual perspectives and at least two or more dimensions of the strategic decision process are taken into account as 
influences, to reduce the chance of testing influences in too much isolation. Avoiding the use of narrow studies is likely to help prevent decision failures or errors by having the potential for counterbalancing effects (as we can see from the mixed findings of context on the strategic decision process).

Second, practitioners should take heed of 'links between contextual perspectives and their different roles.' In this review, we made a point of the spatial and temporal ordering of the elements in the unfolding of the strategic decision process. Contextual perspectives and the influences from various perspectives do not drive the entire strategic decision process for its full duration. Most quantitative research takes little or no account of where in the process (spatial aspect), or of when and how continuously in the process (temporal aspect) contextual perspectives and influences become active and impinge on the strategic decision process. We recommend practitioners to repeatedly pose the question why certain perspectives and influences should be considered during the strategic decision process, and to place them on the timeline of the process and conceive of the links between these influences for any specific strategic decision process. In other words, next to relying on the evidence in terms of effects and their sizes, part of the analysis should cover the mechanisms or more qualitative background narratives on where, when, and how influences impinge on the strategic decision process.

\section{Recommendations for future research}

Based on our in-depth review of the literature, we have identified seven directions for future research as discussed below.

First, future studies should consider the examination of more complex relationships (e.g., two- and three-way interactions, mediation, and curvilinear) than simply the main effects of constructs from the four perspectives on strategic decision processes. Our literature review indicates that most studies in the area test for the main or direct effects of the four different perspectives on strategic decision processes. However, the case may be that the variables within the same perspective interact and this interaction deserves further theoretical and empirical investigation. Similarly, it could be argued that the interaction between the four perspectives could add to the explained percentage of variance in the dependent variable over and above their direct effects. In the only exception in the literature that is looking for such relationships, Brouthers, Brouthers, and Werner (2000) in a Dutch setting show that managerial characteristics such as age, education and risk propensity limit the influence of external factors (i.e., turbulence) and internal ones (i.e., structure, entrepreneurial style) on strategic aggressiveness. Similar interaction effects may be relevant in explaining other strategic decision processes, such as comprehensiveness, political behavior, and intuition (Elbanna et al., 2014). Given the suggestion in the upper echelon theory
(Finkelstein et al., 2009) and the related literature that the demographic and psychological characteristics of top managers may limit the influence of external and internal factors on the strategic decision processes by restricting information search and retrieval activities, we argue that it is time to test for such effects with empirical data.

On a related note, researchers should test for the possibility of mediation effects among the four perspectives. For example, organization and decision characteristics may mediate the effects of environmental factors on strategic decision processes. More specifically, it could be argued that environmental uncertainty and hostility damage company performance (see Baum \&Wally, 2003 for more on this). If they do, then company performance fully mediates the relationship between environmental uncertainty, hostility, and strategic decision processes. Similarly, it could be argued that environmental uncertainty and hostility increase decision uncertainty; if so, then decision uncertainty fully mediates the relationship between uncertainty, hostility, and comprehensiveness. The latter result suggests that the effect of environmental factors may be filtered through the characteristics of the decision (the decision-specific factors), as well. Thus, there is a need to investigate the empirical data on such possible mediating mechanisms.

Second, there is a need to use more overarching, latent constructs to capture the personality of a CEO and of the top managers. Hitherto, all studies in the strategic decision process area have examined individual aspects of the CEO's personality. These studies, although important, have not considered multiple personality characteristics together and, most importantly, have not investigated their possible interrelationships and overlaps with each other (Judge, Erez, Bono, \& Thoresen, 2003). Recent developments in the strategy and organizational behavior literature suggest that characteristics such as core-self-evaluation, hubris and the five-factor model deserve further theoretical and empirical attention (Hiller \& Hambrick, 2005; Nadkarni \& Herrmann, 20 10). To the best of our knowledge, such constructs have not been studied in the context of strategic decision processes.

Third, apart from a few exceptions (e.g., Hickson, Miller, \& Wilson, 2003; Nutt, 2008) previous studies adopt a cross-sectional research design. The adoption of such a design limits the ability of researchers to establish causal connections among constructs. Thus, we would welcome studies investigating the context and processes over time (i.e., longitudinal studies). Also, research on strategic decision processes ought to expand beyond the geographic and cultural foci of the United States and include a wider range of organizations than manufacturing firms alone.

Fourth, most of the empirical papers that we reviewed focus on the effects of context on either the formulation or the implementation of a strategic decision. In other words, formulation and implementation are viewed as two distinct 
and independent stages of the strategic decision process. This is not in line with the tenets of the strategy process literature which have long recognized the need to investigate both how decisions are formulated and implemented and how implementation then affects the formulation of subsequent decisions (Elbanna, 2015; Hutzschenreuter \& Kleindienst, 2006). We view this as a notable limitation in the available studies. Future scholars should investigate how formulation and implementation stages are related to each other and unfold over time and how the context shapes this relationship. Answers to such research questions can be provided by adopting longitudinal research designs. What is more, previous studies have mainly theorized and tested a linear sequence from context to formulation, implementation, and outcomes. This sequence is rather static and ignores the dynamic nature of our world. For example, conventional wisdom would suggest that managers consider the outcomes of their decisions when making and implementing new ones. It would also suggest that the experience gained from implementing past strategic decisions will influence the way in which new ones are made and implemented. In Figure I, this can be depicted by adding an arrow from implementation to formulation and from outcomes to process. Such relationships, however, have not been tested with empirical data and again require a longitudinal research design.

Fifth, most of the studies from the top management perspective that we reviewed focus on the demographic diversity of the top managers and make inferences about their cognitive diversity (e.g., Elbanna et al., 2017), because the former can be easily measured on the basis of archival data while the latter requires demanding field research. In a broader sense, this is consistent with the general trend that has been observed over the years in the upper-echelon literature according to which researchers measure demographic characteristics and use them as proxies of psychological ones (Finkelstein et al., 2009). Recent empirical evidence suggests that such practices can lead to biased conclusions, given that demographic characteristics may not be a proxy of psychological characteristics (for a thorough critique, see Lawrence, 1997). In view of the empirical evidence demonstrating how important psychological characteristics such as cognitive diversity are (Miller, Burke, \& Glick, 1998; Samba, Van Knippenberg, \& Miller, 2018), we encourage studies that directly measure psychological characteristics.

Sixth, we believe that future scholars can borrow constructs and ideas from the strategic decision process area and apply them in relevant fields of research, such as the internationalization processes of SMEs, new product development, mergers and acquisitions, strategic alliances, and divestitures. In the recent past, we have seen preliminary efforts in these areas (as an example, see Elbanna, Hsieh, \& Child, 20 I5b). For instance, Dimitratos et al. (20 I la) investigated the relationship between performance and three loci of internationalization decision processes (i.e., formalization, decentralization, and lateral communication) in the international marketplace of SMEs. They found that the first two processes are positively related to performance but the last is not. Slotegraaf and Atuahene-Gima (20I I) examined the antecedents and outcomes of marketing strategy comprehensiveness. Other studies have argued that comprehensiveness is positively related to allocating capital efficiently (Strauch, Pidun, \& Zu Knyphausen-Aufseß, 2019) and divestiture outcomes (Thywissen, Pidun, \& Zu KnyphausenAufsess, 2018). In the area of strategic alliances, Walter, Kellermans, and Lechner (2012) argued that rationality in alliance decision processes positively influences alliance performance. More recently, Kaufmann, Meschnig, and Reimann (2014) have studied the effects of rationality and intuition on the success of supplier decisions. Such cross-disciplinary research could yield interesting theoretical and practical implications and for this reason is much to be welcomed.

On a related note, some studies (Heavey et al., 2009; Thanos et al., 2017) link the dimensions of strategic decision processes with well-known constructs from the entrepreneurship literature such as (international) entrepreneurial orientation, which refers to the tendency of a firm to be proactive, innovative, and risk taking (Wales, 2016). Such research efforts are very useful and welcome, because they help to refine what is known in other streams of the literature and make notable contributions to our level of knowledge. Similarly, although managers use information systems when making decisions, empirical research on the impact of these systems on strategic decision processes and their outcomes is limited. This is rather surprising that previous literature reviews have explicitly called for more research on this topic (e.g., Papadakis et al., 2010), and hence, we view it as an interesting research opportunity.

As a seventh possible direction for future research, we believe that a next step in the relevant area would be to develop a review synthesis that comprehensively captures and maps the literature on strategic decisions. The systematic review undertaken here brought together many works on the contextual factors, but its focus forbade the inclusion of papers on strategic decisions unless they included contextual factors or were empirical. Papers considered pivotal to the field of studying strategic decisions, such as the work of Mintzberg et al. (1976) on the incremental decision process model and the work of Dean and Sharfman (1993b) on the independence of dimensions of the strategic decision process were, thus excluded. Such papers are also foundational to the field and critical for a full understanding of strategic decision-making. An integration of all the relevant empirical works (rather than the subset of work reviewed here) could by means of meta-analysis based on a thorough consideration of the foundational and core literature of the field help to overcome the previously mentioned limitations of construct and measurement diversity. 
The literature would then reach a more comprehensive and meaningful synthesis which would serve as a starting point for scholars interested in the field. On a related note, a more modest first step in such an undertaking could be a review-of-reviews in the field. There have been several review papers that can be considered to have built on one another, such as the work by Huff and Reger (1987), Rajagopalan et al. (1993), Schwenk (1995), Rajagopalan et al. (1997), Hutzschenreuter and Kleindienst (2006), Elbanna (2006), Papadakis et al. (20|0), Shepherd and Rudd (20|4), and Bromiley and Rau (2016). These have not so far been explicitly explored in relation to one another. Although this list is far from complete, a review-of-reviews in combination with the foundational and core literature of the field could provide a careful narrative of the build-up and development of the strategic decision-making field based on its contents and main perspectives. This research direction shows that there is still vast potential to deliver a more comprehensive synthesis of the field, based on the integration of individual empirical papers against a carefully developed background. Both suggestions discussed above would add to the existing literature by functioning as a point for engaging in the academic conversation on strategic decision-making.

In conclusion, this article provided an in-depth review on the role of the broader context in strategic decision processes and, in order to get more insight into this role, identified several future research opportunities for theorists and practitioners alike.

\section{Acknowledgements}

The authors would like to thank Thomas Roulet and three anonymous reviewers for their invaluable feedback on earlier drafts of this article.

\section{References'}

*Abdel-Maksoud, A., Elbanna, S., Mahama, H. \& Pollanen, R. (20।5). The use of performance information in strategic decision making in public organizations. International Journal of Public Sector Management, 28(7), 528-549. doi: 10.1 108/IJPSM-06-2015-01 I4

*Alkaraan, F. \& Northcott, D. (2006). Strategic capital investment decision-making: A role for emergent analysis tools? A study of practice in large UK manufacturing companies. British Accounting Review, 38(2), | 49-173. doi: | 0. I 0 | 6/j.bar.2005. 10.003

*Amason, A. C. (1996). Distinguishing the effects of functional and dysfunctional conflict on strategic decision making: Resolving a paradox for top management teams. Academy of Management Journal, 39(I), |23-| 48. doi: 10.2307/256633

Amason, A. C. \& Mooney, A. C. (2008). The Icarus paradox revisited: How strong performance sows the seeds of dysfunction in future

\footnotetext{
1. Asterisks denote studies resulted from the systematic literature review
}

strategic decision-making. Strategic Organization, 6(4), 407-434. doi: | 0.1 1 777/1476/27008096364

*Ashmos, D. P., Duchon, D. \& McDaniel, R. R. (1998). Participation in strategic decision making: The role of organizational predisposition and issue interpretation. Decision Sciences, 29 ( ), 25-5 I . doi: I 0.1 I I //j. I54059|5.1998.tb0I343.x

*Ashmos, D. P. \& McDaniel, R. R. (1996). Understanding the participation of critical task specialists in strategic decision making. Decision Sciences, 27(1), I03-121. doi: I0.1 | | |/j. I540-59| 5.1996.tb00845.x

Asmuß, B. \& Oshima, S. (20।8). Strategy making as a communicative practice: the multimodal accomplishment of strategy roles. M@n@gement, 2I (2), 884-9 I2. doi: 10.39I7/mana.212.0884

*Atuahene-Gima, K. \& Li, H. Y. (2004). Strategic decision comprehensiveness and new product development outcomes in new technology ventures. Academy of Management Journal, 47(4), 583-597. doi: 10.5465/20159603

*Bailey, B. C. \& Peck, S. I. (20 I 3). Boardroom strategic decision-making style: Understanding the antecedents. Corporate Governance: An International Review, 2 I (2), | 31-|46. doi: I0. I | | //corg. I 2008

*Bantel, K. A. (1993). Top team, environment, and performance effects on strategic-planning formality. Group \& Organization Management, 18(4), 436-458. doi: I0.1 I 77// 05960 I 193 | 84004

*Baum, J. R. \& Wally, S. (2003). Strategic decision speed and firm performance. Strategic Management Journal, 24( I I), I I07-| | 29. doi: I 0. I002/ smj.343

*Bisbe, J. \& Malagueño, R. (20/2). Using strategic performance measurement systems for strategy formulation: Does it work in dynamic environments? Management Accounting Research, 23(4), 296-31 I. doi: I0. I 0 | 6/j.mar.2012.05.002

Boone, C., De Brabander, B. \& van Witteloostuijn, A. (1996). CEO locus of control and small firm performance: An integrative framework and empirical test. Journal of Management Studies, 33(5), 667-699. doi: | 0.1 | | |/j. | 467-6486.1996.tb008|4.x

*Bourgeois, L. J. \& Eisenhardt, K. M. (1988). Strategic decision-processes in high-velocity environments: Four cases in the microcomputer industry. Management Science, 34(7), 816-835. doi: I0.1287/mnsc.34.7.8I6

Boyd, B. K., Bergh, D. D., Ireland, R. D. \& Ketchen, D. J. (20।3). Constructs in strategic management. Organizational Research Methods, I6(I), 3-14. doi: | 0.1 | 77// 094428 | | 247| | 298

Le Bris, S., Madrid-Guijarro, A. \& Martin, D. P. (2019). Decision-making in complex environments under time pressure and risk of critical irreversibility: The role of meta rules. M@n@gement, 22( I), I-29. doi: I0.39। I/ mana.221.000।

Bromiley, P. \& Rau, D. (2016). Social, behavioral, and cognitive influences on upper echelons during strategy process: A literature review. Journal of Management, 42(I), 174-202. doi: I0.1 177/0 I49206315617240

*Brouthers, K. D., Andriessen, F. \& Nicolaes, I. (1998). Driving blind: Strategic decision-making in small companies. Long Range Planning, 3/(I), | 30-138. doi: I0.1016/S0024-630| (97)00099-X

Brouthers, K. D., Brouthers, L. E. \& Werner, S. (2000). Influences on strategic decision-making in the Dutch financial services industry. Journal of Management, 26(5), 863-883. doi: I 0. I 1 I 6/S0 | 49-2063(00)0006 I I

Butler, R. (2002). Decision making. In A. Sorge (Ed.), Organization (pp. 224-25I). London:Thomson Learning.

Calabretta, G., Gemser, G. \& Wijnberg, N. M. (2017). The interplay between intuition and rationality in strategic decision making: $A$ paradox perspective. Organization Studies, 38(3-4), 365-40I. doi: | 0.1 1 77/01708406 | 6655483

Cardinal, L. B., Miller, C. C., Kreutzer, M. W. \& Tenbrink, C. (20I5). Strategic planning and firm performance: Towards a better understanding of 
a controversial relationship. In M. D. Mumford \& M. Frese (Eds.), The psychology of planning in organizations: Research and applications (pp. 260-288). New York, NY: Routledge.

*Carmeli, A., Tishler, A. \& Edmondson, A. C. (20।2). CEO relational leadership and strategic decision quality in top management teams:The role of team trust and learning from failure. Strategic Organization, I O ( I), 31-54. doi: | 0.1 | 177/ |476|270| | 434797

*Cheng, V., Rhodes, J. \& Lok, P. (20I0). A framework for strategic decision making and performance among Chinese managers. International Journal of Human Resource Management, 21(9), 1373-1395. doi: I 0.1080/09585 | 92.2010 .488434

Child, J. (1997). Strategic choice in the analysis of action, structure, organizations and evironment: Retrospect and prospect. Organization Studies, 18(I), 43-76. doi: 10.1 I 77/017084069701800104

Child, J., Elbanna, S. \& Rodrigues, S. (20I0). The political aspects of strategic decision making. In P. C. Nutt \& D. C. Wilson (Eds.), Handbook of decision making (pp. 105-137). Chichester:Wiley.

*Clark, K. D. \& Maggitti, P. G. (20I2). TMT potency and strategic decision-making in high technology firms. Journal of Management Studies, 49(7), I | 68-1 | 93. doi: I 0. I | | |/j. I 467-6486.20 I 2.0 I060.x

*Covin, J. G., Slevin, D. P. \& Heeley, M. B. (200 I). Strategic decision making in an intuitive vs. technocratic mode: Structural and environmental considerations. Journal of Business Research, 52(I), 51-67. doi: 10.1016 / SOI48-2963(99)00080-6

*Dayan, M. \& Di Benedetto, C. A. (20 I I). Team intuition as a continuum construct and new product creativity: The role of environmental turbulence, team experience, and stress. Research Policy, 40(2), 276-286. doi: 10.1016/j.respol.2010.10.002

* Dayan, M., Elbanna, S. \& Di Benedetto, A. (2012). Antecedents and consequences of political behavior in new product development teams. IEEE Transactions on Engineering Management, 59(3), 470-482. doi: | 0.11 109/TEM.2011.2166078

* Dean, J.W. \& Sharfman, M. P. (1993a). Procedural rationality in the strategic decision-making process. Journal of Management Studies, 30(4), 587-6 | 0. doi: | 0.1 | | | /j. I467-6486.1993.tb003 |7.x

Dean, J.W. \& Sharfman, M. P. (1993b).The relationship between procedural rationality and political behavior in strategic decision-making. Decision Sciences, 24(6), |069-| 083. doi: | 0. I | | |/j. I540-59| 5. 1993.tb00504.x

*Dean, J. W. \& Sharfman, M. P. (1996). Does decision process matter? A study of strategic decision making effectiveness. Academy of Management Journal, 39(2), 368-396. doi: 10.2307/256784

*Denis, J.-L. L., Dompierre, G., Langley, A. \& Rouleau, L. (20 I I). Escalating indecision: Between reification and strategic ambiguity. Organization Science, 22( I), 225-244. doi: I0.1287/orsc. 1090.0501

Dess, G. G. \& Beard, D. W. (1984). Dimensions of organizational task environments. Administrative Science Quarterly, 29(I), 52-73. doi: 10.2307/2393080

* Dimitratos, P., Petrou, A., Plakoyiannaki, E. \& Johnson, J. E. (20 I I a). Strategic decision-making processes in internationalization: Does national culture of the focal firm matter? Journal of World Business, 46(2), 194-204. doi: 10.1016/j.jwb.2010.05.002

*Duhaime, I. M. \& Baird, I. S. (1987). Divestment decision-making: The role of business unit size. Journal of Management, 13(3), 483-498. doi: | 0.1 177/01492063870|300305

*Dutton, J. E. \& Duncan, R. B. (1987). The creation of momentum for change through the process of strategic issue diagnosis. Strategic Management Journal, 8(3), 279-295. doi: I0. I002/smj.4250080306

Eisenhardt, K. M. (1989). Making fast strategic decision in high velocity environments. Academy of Management Journal, 32(3), 543-576. doi. 10.5465/256434
Eisenhardt, K. M. \& Zbaracki, M. J. ( 1992). Strategic decision making. Strategic Management Journal, I 3(SI), I7-37. doi: I0. I 002/smj.4250 I 30904

Elbanna, S. (2006). Strategic decision-making: Process perspectives. International Journal of Management Reviews, 8(I), I-20. doi: 1 0.1 I | | /j. . 4688-2370.2006.00 I 18.x

Elbanna, S. (2009). The impact of affective conflict on firm performance. Management Research News, 32(9), 789-803. doi: | 0.1 1 08/0 | 409170910980317

Elbanna, S. (2010). Making strategic decisions: A state of the art review and empirical evidence from a cultural perspective. Dudweiler Landstr: Lambert Academic Publishing.

*Elbanna, S. (20/2). Slack, planning and organizational performance: Evidence from the Arab middle east. European Management Review, 9(2), 99- | | 5. doi: | 0.1 | | |/j. I740-4762.20 | 2.0 I028.x

Elbanna, S. (20/5). Intuition in project management and missing links: Analyzing the predicating effects of environment and the mediating role of reflexivity. International Journal of Project Management, 33(6), |236-1248. doi: I0.1 0 | 6/j.jproman.2015.02.004

*Elbanna, S. (2016). Managers' autonomy, strategic control, organizational politics and strategic planning effectiveness: An empirical investigation into missing links in the hotel sector. Tourism Management, 52, 210-220. doi: 10.1016/j.tourman.2015.06.025

*Elbanna, S. (2018). The constructive aspect of political behavior in strategic decision-making: The role of diversity. European Management Journal, 36(5), 616-626. doi: 10. I0 | 6/j.emj.2018.06.006

*Elbanna, S., Ali, A. J. \& Dayan, M. (20II). Conflict in strategic decision making: Do the setting and environment matter? International Journal of Conflict Management, 22(3), 278-299. doi: | 0.1 | 08/1044406 | | | | 52973

*Elbanna, S. \& Child,J. (2007a). Influences on strategic decision effectiveness: Development and test of an integrative model. Strategic Management Journal, 28(4), 43।-453. doi: I0. I002/smj.597

*Elbanna, S. \& Child, J. (2007b). The influence of decision, environmental and firm characteristics on the rationality of strategic decision-making. Journal of Management Studies, 44(4), 56I-59I. doi: | 0.1 | | |/j. | 467-6486.2006.00670.x

*Elbanna, S., Child, J. \& Dayan, M. (20I3). A model of antecedents and consequences of intuition in strategic decision-making: Evidence from Egypt. Long Range Planning, 46(I-2), 149-176. doi: 10.1016/j. Irp.2012.09.007

*Elbanna, S., Di Benedetto, C. A. \& Gherib, J. (20I5a). Do environment and intuition matter in the relationship between decision politics and success? Journal of Management \& Organization, 2I (1), 60-81. doi: 10.1017/ jmo.2014.65

*Elbanna, S. \& Fadol, Y. (2016a). An analysis of the comprehensive implementation of strategic plans in emerging economies: The United Arab Emirates as a case study. European Management Review, 13(2), 75-89. doi: |0. I | | |/emre. 12068

Elbanna, S. \& Fadol,Y. (20 I 6b).The role of context in intuitive decision-making. Journal of Management \& Organization, 22(5), 642-66। . doi: I 0.1017 I jmo.2015.63

Elbanna, S. \& Gherib, J. (20/2). Miller's environmental uncertainty scale: An extension to the Arab world. International Journal of Commerce \& Management, 22(I), 7-25. doi: 10.1 I08/I 05692 I I 2 I I 204483

Elbanna, S., Hsieh, L. \& Child, J. (2015b). Internationalization of SMEs: A review on decision-making. The 3/st European Group for Organization Studies (EGOS) Colloquium (July 2015). Athens, Greece.

*Elbanna, S., Kapoutsis, I. \& Mellahi, K. (2017). Creativity and propitiousness in strategic decision making: The role of positive politics and 
macro-economic uncertainty. Management Decision. doi: 10.1108/ MD-02-2017-0113

*Elbanna, S. \& Naguib, R. (2009). How much does performance matter in strategic decision making? International Journal of Productivity and Performance Management, 58(5), 437-459. doi: 10.1 108/ 17410400910965715

*Elbanna, S., Thanos, I. C. \& Colak, M. (2015c). An exploratory study of the determinants of the quality of strategic decision implementation in Turkish industrial firms. Journal of General Management, 40(2), 27-46. doi: I 0.1 | 177/03063070 | 404000203

*Elbanna, S., Thanos, I. C. \& Papadakis, V. M. (20।4). Understanding how the contextual variables influence political behaviour in strategic decision-making: A constructive replication. Journal of Strategy and Management, 7(3), I-4I. doi: I0.1 I 08/JSMA-02-20 I4-00 I 3

Elbasha, T. \& Wright, A. (2017). Reconciling structure and agency in strategy-as-practice research: Towards a strong-structuration theory approach. M@n@gement, 20(2), 107-128. doi: 10.3917/ mana.202.0107

*Ericson, M. (2010). Towards a sensed decision-making approach. Management Decision, 48(I), I32-I55. doi: I0. I 108/0025 I 74 I 01 I 014490

*Fiegener, M. K. (2005). Determinants of board participation in the strategic decisions of small corporations. Entrepreneurship Theory and Practice, 29(5), 627-650. doi: I0.1 I | |/j. 1540-6520.2005.00 I01.x

Finkelstein, S., Hambrick, D. C. \& Cannella, A. A. (2009). Strategic leadership: Theory and research on executives, top management teams, and boards. In S. Finkelstein, D. C. Hambrick \& A. A. Cannella (Eds.). Oxford: Oxford University Press.

Forbes, D. P. (2007). Reconsidering the strategic implications of decision comprehensiveness. Academy of Management Review, 32(2), 36 I-376. doi: I0.5465/amr.2007.24349585

*Ford, C. M., Sharfman, M. P. \& Dean, J.W. (2008). Factors associated with creative strategic decisions. Creativity and Innovation Management, 17(3), |7|-| 85. doi: |0. | | | |/j. | 467-869|.2008.00486.x

*Francioni, B., Musso, F. \& Cioppi, M. (2015). Decision-maker characteristics and international decisions for SMEs. Management Decision, 53( I0), 2226-2249. doi: 10.1 108/MD-03-2015-0094

Fredrickson, J. W. (1984). The comprehensiveness of strategic decision processes: Extension, observations, future directions. Academy of Management Journal, 27(3), 445-466. doi: I0.2307/256039

*Fredrickson, J. W. (1985). Effects of decision motive and organizational performance level on strategic decision processes. Academy of Management Journal, 28(4), 82 I-843. doi: I0.2307/256239

Fredrickson, J. W. \& laquinto, A. L. (1989). Inertia and creeping rationality in strategic decision-processes. Academy of Management Journal, 32(3), 5 | 6-542. doi: 10.2307/256433

Fredrickson, J. W. \& Mitchell, T. R. (1984). Strategic decision processes: Comprehensiveness and performance in an industry with an unstable environment. Academy of Management Journal, 27(2), 399-423. doi: 10.2307/255932

*Friedman, Y., Carmeli, A. \& Tishler, A. (20I6). How CEOs and TMTs build adaptive capacity in small entrepreneurial firms. Journal of Management Studies, 53(6), 996-1018. doi: 10.1 | | | /joms. 12184

Gavetti, G., Greve, H. R., Levinthal, D. A. \& Ocasio,W. (2012). The behavioral theory of the firm: Assessment and prospects. Academy of Management Annals, I, I-40. doi: I0. I080/| 94 | 6520.20 |2.65684 |

*Goll, I. \& Rasheed, A. A. (2005). The relationships between top management demographic characteristics, rational decision making, environmental munificence, and firm performance. Organization Studies, 26(7), 999- | 023. doi: 10.1 177/0 |70840605053538

*Goll, I. \& Rasheed, A. M. A. (1997). Rational decision-making and firm performance: The moderating role of environment.
Strategic Management Journal, 18(7), 583-591. doi: 10.1002/ (SICl) I097-0266( | 199708) | 8:7<583::AID-SMJ907>3.0.CO;2-Z

Greening, D.W. \& Johnson, R. A. (1996). Do managers and strategies matter? A study in crisis. Journal of Management Studies, 33(I), 25-5 I. doi: | 0. 1 | | | /j. | 467-6486. 1996.tb00797.x

Greenwood, R., Magan Diaz, A., Li, S. X. \& Cespedes Lorente, J. (2010). The multiplicity of institutional logics and the heterogeneity of organizational responses. Organization Science, 2 I (2), 52 I-539. doi: I0.1287/ orsc. 1090.0453

*Gu, J., Weng, Q. \& Xie, F. (20I2). Leadership, team and decision speed: Empirical study using cross-provincial data. Chinese Management Studies, 6(4), 598-609. doi: 10.1 108/17506/4121 |28028 |

Halikias, J. \& Panayotopoulou, L. (2003). Chief executive personality and export involvement. Management Decision, 4 I (4), 340-349. doi: | 0.1 | 08/0025 |740310468072

Hambrick, D. C. (2007). Upper echelons theory: An update. Academy of Management Review, 32(2), 334-343. doi: 10.5465/ amr.2007.24345254

Hambrick, D. C. \& Mason, P.A. (1984). Upper echelons:The organization as a reflection of its top managers. Academy of Management Review, 9(2), 193-206. doi: 10.2307/258434

Hautz, J. (2017). Opening up the strategy process: A network perspective. Management Decision, 55(9), 1956- I 983. doi: I 0.I I 08/MD-07-20 I 6-05 I0

Heavey, C., Simsek, Ketchen, D. J., Boyd, B. K. \& Bergh, D. D. (2008). Research methodology in strategic management: Past accomplishments and future challenges. Organizational Research Methods, I I (4), 643-658. doi: 10.1 177/1094428108319843

Heavey, C., Simsek, Z., Roche, F. \& Kelly, A. (2009). Decision comprehensiveness and corporate entrepreneurship: The moderating role of managerial uncertainty preferences and environmental dynamism. Journal of Management Studies, 46(8), I289-1314. doi: | 0.1 | | |/j. | 467-6486.2009.00858.x

*Henderson, A. D., Miller, D. \& Hambrick, D. C. (2006). How quickly do CEOs become obsolete? Industry dynamism, CEO tenure, and company performance. Strategic Management Journal, 27(5), 447-460. doi: 10.1002/smj.524

*Hensman, A. \& Sadler-Smith, E. (20I I ). Intuitive decision making in banking and finance. European Management Journal, 29(I), 5 I-66. doi: I0. I 1 I 6/j. emj.2010.08.006

Hickson, D. J., Miller, S. J. \& Wilson, D. C. (2003). Planned or prioritized? Two options in managing the implementation of strategic decisions. Journal of Management Studies, 40(7), I803-1836. doi: | 0. | | | | | | 467-6486.0040 |

Hiller, N. J. \& Hambrick, D. C. (2005). Conceptualizing executive hubris: The role of (hyper-)core self-evaluations in strategic decision-making. Strategic Management Journal, 26(4), 297-319. doi: I0. I002/smj.455

*Hitt, M. A. \& Ireland, R. D. (1986). Relationships among corporate level distinctive competencies, diversification strategy, corporate structure and performance. Journal of Management Studies, 23(4), 40 I-4I 6. doi: | 0. 1 | | | /j. | 467-6486. 1986.tb00425.x

*Hitt, M. A. \& Tyler, B. B. (199|). Strategic decision models: Integrating different perspectives. Strategic Management Journal, 12(5), 327-35I. doi: I0.1002/smj.4250 I 20502

*Hough, J. R. \& White, M. A. (2003). Environmental dynamism and strategic decision-making rationality: An examination at the decision-level. Strategic Management Journal, 24(5), 48 I-489. doi: I0. I002/smj.303

Huff, A. S. \& Reger, R. K. (1987). A review of strategic process research. Journal of Management, 13(2), 211-236. doi: I 0.1 | 77//0 | 492063870| 300203

*Hurt, K. J. \& Abebe, M. A. (20I5). The effect of conflict type and organizational crisis on perceived strategic decision effectiveness: An empirical 
investigation. Journal of Leadership \& Organizational Studies, 22(3), 340354. doi: 10.1 | 177// 54805 | 8 | 5570038

Hutzschenreuter,T. \& Kleindienst, I. (2006). Strategy-process research:What have we learned and what is still to be explored. Journal of Management, 32(5), 673-720. doi: | 0. I I77/0 | 4920630629 | 485

*laquinto, A. L. \& Fredrickson, J.W. (1997). Top management team agreement about the strategic decision process: A test of some of its determinants and consequences. Strategic Management Journal, I 8(I), 63-75. doi: | 0. I 002/(SICl) | 097-0266 ( 19970 | | | 8: | <63::AID-SMJ835>3.0.CO;2-N

*Jackson, S. E. \& Dutton, J. E. (1988). Discerning threats and opportunities. Administrative Science Quarterly, 33(3), 370-387. doi: 10.2307/23927/4

*Jansen, R.J.G., Curşeu, P. L., Vermeulen, P. A. M., Geurts, J. L. A. \& Gibcus, P. $(20 \mathrm{II})$. Social capital as a decision aid in strategic decision-making in service organizations. Management Decision, 49(5). doi: |0.1 |08/0025 |74| | | | |30823

*Jansen, R. J. G., Curşeu, P. L., Vermeulen, P.A. M., Geurts, J. L. A. \& Gibcus, P. (20I3). Information processing and strategic decision-making in small and medium-sized enterprises: The role of human and social capital in attaining decision effectiveness. International Small Business Journal, 3 I (2), |92-2 | 6. doi: | 0.| | 177/02662426 | 4066762

Jemison, D. B. (1984). The importance of boundary spanning roles in strategic decision-making. Journal of Management Studies, 2 I (2), I 3 | - 152. doi: | 0. I | | | /j. | 467-6486. 1984.tb00228.x

Ji, J. \& Dimitratos, P. (20/3). An empirical investigation into international entry mode decision-making effectiveness. International Business Review, 22(6), 994-1007. doi: 10.10 I6/j.ibusrev.20 I3.02.008

Judge, T. A., Erez, A., Bono, J. E. \& Thoresen, C. J. (2003). The core self-evaluations scale: Development of a measure. Personnel Psychology, 56(2), 303-331. doi: I0. 1 | | | //j. I744-6570.2003.tb00 I 52.x

*Judge, W. Q. \& Miller, A. (|99|). Antecedents and outcomes of decision speed in different environmental contexts. Academy of Management Journal, 34(2), 449-463. doi: I0.2307/25645 |

Kaufmann, L., Meschnig, G. \& Reimann, F. (20 I4). Rational and intuitive decision-making in sourcing teams: Effects on decision outcomes. Journal of Purchasing and Supply Management, 20(2), 104-1 12. doi: 10.1016/j. pursup.2014.03.003

Ketchen, D. J., Boyd, B. K. \& Bergh, D. D. (2008). Research methodology in strategic management: Past accomplishments and future challenges. Organizational Research Methods, II(4), 643-658. doi: I0.1177/1094428108319843

*Klingebiel, R. \& De Meyer, A. (20।3). Becoming aware of the unknown: Decision making during the implementation of a strategic initiative. Organization Science, 24( I), I33-I 53. doi: I 0. I 287/orsc. I I 0.0726

*Langley, A. (1989). In search of rationality: The purposes behind the use of formal analysis in organizations. Administrative Science Quarterly, 34(4), 598-631. doi: 10.2307/2393569

Langley, A. (2007). Process thinking in strategic organization. Strategic Organization, 5(3), 27|-282. doi: | 0.1 | 777/ |476|27007079965

Langley, A, \& Abdallah, C. (201 I). Templates and turns in qualitative studies of strategy and management. In D. D. Bergh \& D. L. Ketchen (Eds.), Research Methodology in Strategy and Management (Vol. 6, pp. 20 I-235). doi: | 0.1 1 08/S | 479-8387(20 I I)0000006007

Langley, A., Mintzberg, H., Pitcher, P., Posada, E. \& Saint-Macary, J. (1995). Opening up decision making:The view from the black stool. Organization Science, 6(3), 260-279. doi: I0.1287/orsc.6.3.260

Langley, A., Smallman, C., Tsoukas, H. \& Van de Ven, A. H. (2013). Process studies of change in organization and management: Unveiling temporality, activity and flow. Academy of Management Journal, 56(1), I-13. doi: | 0.5465/amj.2013.400 |

Lawrence, B. S. (1997). The black box of organizational demography. Organization Science, 8(I), I-22. doi: I0. I 287/orsc.8. I.I
Lewin, A. Y. \& Stephens, C. U. (1994). CEO attitudes as determinants of organization design: An integrated model. Organization Studies, 15(2), | 83-2 | 2. doi: I0.1 | 777/0 |708406940| 500202

*Lyles, M. A. (1981). Formulating strategic problems: Empirical analysis and model development. Strategic Management Journal, 2(I), 6I-75. doi: | 0.2307/248599|

*Lyles, M. A. \& Mitroff, I. I. (1980). Organizational problem formulation: An empirical study. Administrative Science Quarterly, 25( I), 102-1 19. doi: 10.2307/2392229

*Mannor, M. J., Wowak, A. J., Bartkus, V. O. \& Gomez-Mejia, L. R. (20।6). Heavy lies the crown? How job anxiety affects top executive decision making in gain and loss contexts. Strategic Management Journal, 37(9), 1968-1989. doi: 10.1002/smj.2425

*Meissner, P. \& Wulf,T. (20I4). Antecedents and effects of decision comprehensiveness: The role of decision quality and perceived uncertainty. European Management Journal, 32(4), 625-635.

Miller, C. C. (2008). Decisional comprehensiveness and firm performance: Towards a more complete understanding. Journal of Behavioral Decision Making, 2 I (5), 598-620. doi: I0. I 002/bdm.607

Miller, C. C., Burke, L. M. \& Glick, W. H. (1998). Cognitive diversity among upper-echelon executives: Implications for strategic decision processes. Strategic Management Journal, 19(1), 39-58. doi: 10.1002/ (sici) | 097-0266 (19980 I ) 19: I <39::aid-smj932>3.0.co;2-a

*Miller, D., Dröge, C. \& Toulouse, J.-M. (1988). Strategic process and content as mediators between organizational context and structure. Academy of Management Journal, 3I (3), 544-569. doi: 10.5465/256459

*Miller, D. \& Friesen, P. H. (1983). Strategy-making and environment: The third link. Strategic Management Journal, 4(3), 221-235. doi: 10.1002/ smj.4250040304

*Miller, D., Kets De Vries, M. F. R. \& Toulouse, J.-M. (1982). Top executive locus of control and its relationship to strategy-making, structure, and environment. Academy of Management Journal, 25(2), 237-253. doi: $10.2307 / 255988$

*Miller, D. \& Toulouse, J.-M. (1986). Chief executive personality and corporate strategy and structure in small firms. Management Science, 32(I I), |389-1409. doi: 10.1287/mnsc.32.1 I.1389

Mintzberg, H., Raisinghani, D. \& Théorêt, A. (1976). The structure of 'unstructured' decision processes. Administrative Science Quarterly, 2 I (2), 246-275. doi: I0.2307/2392045

*Mitchell, J. R., Shepherd, D. A. \& Sharfman, M. P. (20I I). Erratic strategic decisions: When and why managers are inconsistent in strategic decision making. Strategic Management Journal, 32(7), 683-704. doi: I 0.1002 I smj.905

*Mueller, G. C., Mone, M. A. \& Barker III,V. L. (2007). Formal strategic analyses and organizational performance: Decomposing the rational model. Organization Studies, 28(6), 853-883. doi: I 0.1 I 77/0 I 70840607075262

Nadkarni, S. \& Herrmann, P. O. L. (20 I 0). CEO personality, strategic flexibility, and firm performance: The case of the Indian business process outsourcing industry. Academy of Management Journal, 53(5), 1050-1073. doi: 10.5465/AMJ.2010.54533196

*Nooraie, M. (2008). Decision magnitude of impact and strategic decision-making process output:The mediating impact of rationality of the decision-making process. Management Decision, 46(4), 640-655. doi: | 0.1 1 08/0025 |740810865102

*Nutt, P. C. (1990). Strategic decisions made by top executives and middle managers with data and process dominant styles. Journal of Management Studies, 27(2), 173-194. doi: I0.1 I I I/j. I 467-6486. 1990.tb00759.x

*Nutt, P. C. (1993). Flexible decision styles and the choices of top executives. Journal of Management Studies, 30(5), 695-721. doi: I0.1 I I I/ j. | 467-6486. 1993.tb00322.x 
Nutt, P. C. (2008). Investigating the success of decision making processes. Journal of Management Studies, 45(2), 425-455. doi: | 0.1 | | |/j. | 467-6486.2007.00756.x

*Papadakis, V. M. (2006). Do CEOs shape the process of making strategic decisions? Evidence from Greece. Management Decision, 44(3), 367-394. doi: | 0.1 | 08/0025 |7406 |0656269

*Papadakis, V. M. \& Barwise, P. (2002). How much do CEOs and top managers matter in strategic decision-making? British Journal of Management, | 3( I), 83-95. doi: | 0.1 | | | | | 467-855 |.00224

*Papadakis, V. M., Lioukas, S. \& Chambers, D. (1998). Strategic decision-making processes: The role of management and context. Strategic Management Journal, 19(2), II5-147. doi: 10.1002/ (SICl) | 097-0266( | 99802) | 9:2<1 | 5::AID-SMJ94 |>3.0.CO;2-5

Parayitam, S. \& Dooley, R. S. (2009). The interplay between cognitive- and affective conflict and cognition- and affect-based trust in influencing decision outcomes. Journal of Business Research, 62(8), 789-796. doi: 10.10 | 6/j.jbusres.2008.02.006

Pettigrew, A. M. (1992). The character and significance of strategy process research. Strategic Management Journal, I3(S2), 5-16. doi: I0. 1002 I smj.4250। 30903

Pettigrew, A. M. (1997). What is a processual analysis? Scandinavian Journal of Management, I 3(4), 337-348. doi: I 0. I 0 I 6/S0956-522 I (97)00020- I

*Pollanen, R., Abdel-Maksoud, A., Elbanna, S. \& Mahama, H. (2017). Relationships between strategic performance measures, strategic decision-making, and organizational performance: Empirical evidence from Canadian public organizations. Public Management Review, 19(5), 725-746. doi: I0.1080/I47| 9037.2016.1203013

*Priem, R. L., Rasheed, A. M. A. \& Kotulic, A. G. (1995). Rationality in strategic decision-processes, environmental dynamism and firm performance. Journal of Management, 21(5), 913-929. doi: I 0.1 1 77/014920639502100506

Rajagopalan, N., Rasheed, A. M. A. \& Datta, D. K. (1993). Strategic decision processes: Critical review and future directions. Journal of Management, 19(2), 349-384. doi: I 0. 101 6/0 I 49-2063(93)90057-t

Samba, C., Tabesh, P.,Thanos, I. C. \& Papadakis, V. M. (in press). Method in the madness? A meta-analysis on the strategic implications of decision comprehensiveness. Strategic Organization. doi: I0. I I77/| 476 I 27020904973

Samba, C., Van Knippenberg, D. \& Miller, C. C. (2018). The impact of strategic dissent on organizational outcomes: A meta-analytic integration. Strategic Management Journal, 39(2), 379-402. doi: I0. I 002/smj.27I0

Schwenk, C. R. (1988). The cognitive perspective on strategic decisionmaking. Journal of Management Studies, 25(1), 4I-55. doi: 10.1 III/ j. 1 467-6486. 1988.tb00021.x

Schwenk, C. R. (1990). Conflict in organizational decision making: An exploratory study of its effects in for- profit and not-for-profit organizations. Organization Science, 36(4), 436-448. doi: I0. I287/mnsc.36.4.436

Schwenk, C. R. (1995). Strategic decision making. Journal of Management, 2I (3), 47 I-493. doi: I 0.1 I 177/0 | 4920639502 I00304

Selart, M. (2005). Understanding the role of locus of control in consultative decision-making: A case study. Management Decision, 43(3), 397-4I2. doi: I0.1 108/0025 I7405 I0589779

*Sharfman, M. P. \& Dean, J.W. (1997). Flexibility in strategic decision making: Informational and ideological perspectives. Journal of Management Studies, 34(2), | 9|-2 17. doi: I 0.1 I | | | 467-6486.00048

Shepherd, N. G. \& Rudd, J. M. (20।4). The influence of context on the strategic decision-making process: A review of the literature. International Journal of Management Reviews, I 6(3), 340-364. doi: I 0. I I I //ijmr. I 2023
*Simons, T., Pelled, L. H. \& Smith, K. A. (1999). Making use of difference: Diversity, debate, and decision comprehensiveness in top management teams. Academy of Management Journal, 42(6), 662-673. doi: 10.2307/256987

Slotegraaf, R. J. \& Atuahene-Gima, K. (201 I). Product development team stability and new product advantage:The role of decision-making processes. Journal of Marketing, 75(1), 96-108. doi: 10.1509/ jmkg.75.1.96

* Souitaris, V. \& Maestro, B. M. M. (20 I 0). Polychronicity in top management teams: The impact on strategic decision processes and performance of new technology ventures. Strategic Management Journal, 3 I (6), 652-678. doi: |0. I002/smj.83|

Strauch, M., Pidun, U. \& Knyphausen-Aufseß, D. zu. (2019). Process matters - How strategic decision-making process characteristics impact capital allocation efficiency. Long Range Planning, 52(2), 202-220. doi: I0. 101 6/j. Irp.2018.04.003

Szulanski, G., Porac, J. \& Doz,Y. (2005). Strategy process: Introduction to the volume. Advances in Strategic Management, 22, xiii-xxxv. doi: 10.1016/ S0742-3322(05)22019-3

*Talaulicar,T., Grundei, J. \& von Werder,A. (2005). Strategic decision making in start-ups: The effect of top management team organization and processes on speed and comprehensiveness. Journal of Business Venturing, 20(4), 5 I9-54 I. doi: | 0. 10 | 6/j.jbusvent.2004.02.00 I

Thanos, I. C., Dimitratos, P. \& Sapouna, P. (20 I 7). The implications of international entrepreneurial orientation, politicization, and hostility upon SME international performance. International Small Business Journal, 35(4), 495-5 |4. doi: | $0.1 \mid$ 177/02662426| $664 \mid 749$

Thomas, L. \& Ambrosini, V. (20 I5). Materializing strategy: The role of comprehensiveness and management controls in strategy formation in volatile environments. British Journal of Management, 26(I), SI 05-SI24. doi: | 0.1 | | | || 467-855 |. | 2075

Thywissen, C., Pidun, U. \& zu Knyphausen-Aufsess, D. (2018). Process matters-The relevance of the decision making process for divestiture outcomes. Long Range Planning, 5I (2), 267-284. doi: I0.1016/j. Irp.2017.04.002

Van de Ven, A. H. (1992). Suggestions for studying strategy process: A research note. Strategic Management Journal, I3(SI), 169-188. doi: 10.1002/smj.4250131013

Wales, W. J. (2016). Entrepreneurial orientation: A review and synthesis of promising research directions. International Small Business Journal, 34(I), 3-15. doi: I0. I 177/02662426/56|3840

*Wally, S. \& Baum, J. R. (1994). Personal and structural determinants of the pace of strategic decision-making. Academy of Management Journal, 37(4), 932-956. doi: 10.2307/256605

Walter, J., Kellermanns, F. W. \& Lechner, C. (20/2). Decision making within and between organizations: Rationality, politics, and alliance performance. Journal of Management, 38(5), 1582-1610. doi: 10.1 177/0149206310363308

*Walters, B. A. \& Bhuian, S. N. (2004). Complexity absorption and performance: A structural analysis of acute-care hospitals. Journal of Management, 30(I), 97-121. doi: 10.1016/j.jm.2003.01.005

*Wiersema, M. F. \& Bantel, K. A. ( 1992). Top management team demography and corporate strategic change. Academy of Management Journal, 35( I), 9 I- I I I. doi: I0.5465/256474

Wu, S., Levitas, E. \& Priem, R. L. (2005). CEO tenure and company invention under differing levels of technological dynamism. Academy of Management Journal, 48(5), 859-873. doi: I 0.2307/20 I59702 